\title{
Constitutional innovation as a political science
}

\author{
S. A. Denisov ${ }^{1}$
}

${ }^{1}$ Humanities University of Yekaterinburg, 19 Studencheskaya str., Yekaterinburg 620049, Russian Federation

DOI: $10.18255 / 2412-6519-2021-2-122-133$

Research Article

Full text in Russian

The article describes the object, subject, main properties, tasks and functions of the science "constitutional innovation". It is a science that studies the implementation of constitutional ideas developed by political philosophy in the life of society. This implementation is carried out throughout the world, in individual countries and at the local level. Based on the subject of the study, the structure of the science "constitutional innovation" is described. Within it, a general theory is distinguished, which studies the laws of the transition of the world and individual countries from the pre-constitutional system to the constitutional one. She answers questions about the possibility of transition of all countries of the world to constitutionalism, about the ways of this transition. In the course of the movement towards constitutionalism, there is usually a stage of imitation of the constitutional system. Part of constitutional innovation should be constitutional deviantology, which studies deviations from the ideals of constitutionalism, the factors that cause them. The General theory develops methods of cognition of this world process. According to the author, the study of the subject of research should be based on dialectics, a materialistic approach using the ideas of Enlightenment, modernization theories, democratic transit, diffusion theory, and conflict theory. Constitutional innovation includes the history of the world's movement towards constitutionalism. On the basis of the known regularities, forecasts of the constitutionalization of the world and individual countries are built. Constitutional innovation performs applied tasks. It helps supporters of constitutionalism to form programs for the promotion of constitutional ideas in the life of society. A separate area of research is the introduction of constitutional ideas through international relations. Constitutional countries are trying to build the whole world in their own image. Science evaluates the effectiveness of the measures applied.

Keywords: constitutional innovation; constitutionalism; constitutional norms; political system; forecasts; science

INFORMATION ABOUT THE AUTHORS

\author{
Denisov, Sergey A. $\quad$ E-mail: Sa-denisov@yandex.ru \\ (correspondence author) ORCID 0000-0003-0544-7330 \\ Cand. Sc. (Jurisprudence), Associate Professor
}

For citation: Denisov S. A. Constitutional innovation as a political science // Social'nye i gumanitarnye znanija. 2021. Vol. 7, No 2. P. 122-133. (in Russ.)

(C) Denisov S. A., 2021

This is an open access article under the CC BY license (https://creativecommons.org/licenses/by/4.0/) 


\section{Конституционная инноватика как политическая наука}

\section{С. А. Денисов ${ }^{1}$}

1Гуманитарный университет г. Екатеринбурга, ул. Студенческая, 19, Екатеринбург, 620049, Российская Федерация

DOI: $10.18255 / 2412-6519-2021-2-122-133$

удк 32

Научная статья Полный текст на русском языке

Статья описывает объект, предмет, основные свойства, задачи и функции науки «конституционная инноватика». Это наука, изучающая внедрение конституционных идей, выработанных политической философией, в жизнь общества. Это внедрение осуществляется в рамках всего мира, в отдельных странах и на локальном уровне. На основе предмета исследования описывается структура науки «конституционная инноватика». Внутри нее выделяется общая теория, изучающая закономерности перехода мира и отдельных стран от доконституционного строя к конституционному. Она отвечает на вопросы о возможности перехода всех стран мира к конституционализму, о путях этого перехода. В ходе движения к конституционализму обычно имеет место стадия имитации конституционного строя. Частью конституционной инноватики должна быть конституционная девиантология, изучающая отклонения от идеалов конституционализма, факторы, их вызывающие. Общая теория вырабатывает методы познания этого мирового процесса. По мнению автора, изучение предмета исследования должно строиться на основе диалектики, материалистического подхода с использованием идей Просвещения, теорий модернизации, демократического транзита, диффузионной теории, теории конфликтов. Конституционная инноватика включает в себя историю движения мира к конституционализму. На основе познанных закономерностей строятся прогнозы конституционализации мира и отдельных стран. Конституционная инноватика выполняет прикладные задачи. Она помогает сторонникам конституционализма формировать программы продвижения конституционных идей в жизнь общества. Отдельным направлением исследования является внедрение конституционных идей посредством международных отношений. Конституционные страны пытаются построить весь мир по своему образу и подобию. Наука оценивает эффективность применяемых мер.

Ключевые слова: конституционная инноватика; конституционализм; конституционные нормы; политическая система; прогнозы; наука

ИНФОРМАЦИЯ ОБ АВТОРАХ

Денисов, Сергей Алексеевич (автор для корреспонденции)

E-mail: Sa-denisov@yandex.ru ORCID 0000-0003-0544-7330

Кандидат юридических наук., доцент кафедры прав человека юридического факультета

Для цитирования: Денисов С. А. Конституционная инноватика как политическая наука // Социальные и гуманитарные знания. 2021. Том 7, № 2. С. 122-133.

(C) Денисов С. А., 2021

Статья открытого доступа под лицензией СС BY (https://creativecommons.org/licenses/by/4.0/) 
В России появилось новое направление исследований, которое получило название «конституционная инноватика». Следует определиться с объектом и предметом этого направления научного исследования, его целями, задачами и функциями.

1. Судя по названию, это юридическая наука. Но если посмотреть на предмет ее исследования, то выяснится, что она носит политологический характер.

Понятие конституционной нормы, как известно, дает не юриспруденция, а политическая философия. Сначала была идея ограничения власти государственного аппарата, идея прав человека и гражданина, идея разделения властей и правового государства. Только по истечении какого-то времени эти идеи стали юридическими терминами. Само понятие «конституция» можно рассматривать не как юридический, а как политологический термин. Под ним предлагается понимать систему норм, которые отражают определенные общественные идеалы: социократию, верховенство прав человека, республику, демократию и т. д. Эти нормы могут закрепляться в нормативном акте или оставаться только в сознании людей. Конституция в умах людей появляется до принятия особого нормативного акта государства. Политическая философия выделяет особый вид конституционной идеологии, называемый конституционализмом. Эта идеология содержит ряд универсальных для всего мира идей и обосновывает их ценность.

Разные направления исследования конституционной инноватики могут иметь разную степень нормативности. Здесь возможен крайний догматизм, уверенность, что определенные конституционные ценности должны рассматриваться как непререкаемые. Меньшая нормативность возникает при установке исследователя на то, что ряд ценностей, которые получают названия конституционные, могут с разной степенью вероятности реализоваться в практике сначала отдельных стран, а затем и во всех странах мира. Этот подход исключает фатализм.

Объектом исследования конституционной инноватики являются процессы внедрения конституционных норм и принципов, рожденных политической философией, в жизнь общества. Эти процессы следует рассматривать на трех уровнях. Внедрение конституционных норм в жизнь всего человечества (мировой процесс), в жизнь отдельных стран и на локальном уровне (на отдельных территориях и в небольших сообществах).

2. Предмет исследования конституционной инноватики является основой для структурирования науки на разделы. Очевидно, что необходимо выделять общую теорию конституционной инноватики, которая должна ответить на многие вопросы, касающиеся развития мира. Первейшим является вопрос о том, движется ли весь мир от доконституционного строя к конституционному? Если взять последние 300 лет, то ответ кажется положительным. Конституционный строй, сначала зародившийся в Англии и Соединенных Штатах, постепенно распространился на всю Европу. Сегодня к нему перешли большинство стран Латинской Америки. Многие страны Азии и Африки не перешли к конституционализму, но для того чтобы выжить, вынуждены имитировать этот переход.

Консерваторы разных стран мира стремятся убедить окружающих, что не все страны мира способны перейти к конституционным отношениям. В определенной степени эта идея носит расистский характер. По мнению консерваторов, конституционализм способен воспринять только белый человек (страны Запада). Этот тезис легко отрицается фактами. К конституционному строю перешли Япония, Южная Корея, Тайвань. Борьба за конституционализм идет во всех странах Азии и Африки.

Вполне объяснимо нежелание правящих групп ряда стран попасть под контроль своего общества. Для сохранения своей власти над обществом они убеждают его, что не 
следует идти по этому «порочному пути». Архаичные, доконституционные отношения авторитаризма и патернализма объявляются традиционными ценностями отдельных народов, от которых нельзя отказываться. Все эти слова произносились аристократами в послереволюционной Франции, консерваторами в Японии периода революции Мэйдзи. История показала, что развитие человечества остановить невозможно. Консерваторы могут только замедлить движение своих народов к демократии и республике.

Другой важный вопрос, который должна решить общая теория конституционной инноватики: универсален ли путь движения всех стран мира к конституционализму? Ответ очевиден. Страны, сильно различающиеся между собой, идут к конституционализму своими путями. У Англии этот путь был медленный, преимущественно через реформы. Франция шла к конституционализму через череду революций. Германия и Япония перешли к конституционализму только после разгрома их во Второй мировой войне. Следует отметить, что капитализм как основа конституционализма был построен в Германии сверху, при активной поддержке государства. По этому же пути пошла Япония и идет сегодня Китай. Страны, имеющие сходные характеристики, идут к конституционализму приблизительно одним путем. Так, в литературе выделяют путь, по которому шли к конституционализму страны Латинской Америки. Относительно общим путем пришли к конституционализму страны Восточной и Южной Европы после развала СССР.

Как любая наука, конституционная инноватика должна выявлять общие закономерности изучаемых явлений. С точки зрения материалистического подхода конституционный строй может возникнуть только в буржуазных странах, где есть слой предпринимателей, способный подчинить себе государственную бюрократию, поставить ее на службу обществу. Другими словами, господствующий административный класс [см.: 1, с. 90-253] должен превратиться в идеальную бюрократию М. Вебера. В условиях рыночных отношений буржуазия делится на группы, конкурирующие между собой за власть. Они выделяют слой публичных политиков, объединенных в партии. Борющиеся между собой партии втягивают в политическую жизнь широкие слои населения. Таким образом, естественным путем возникает демократический политический режим. Буржуазия привыкла к договорным отношениям. Из экономики они переносятся в политику. Борьба и поиск компромиссов между разными группами общества переносится в парламент. Так возникает республика. Там, где класс буржуазии слаб, господствующее положение над обществом с неизбежность захватывает административный класс, из которого состоит государственный аппарат. Буржуазия вынуждена стать клиентелой этого класса. Без сильного класса буржуазии не может появиться гражданской интеллигенции, которая занимается пропагандой конституционализма. Административный класс порождает слой служилой интеллигенции [1, с. 273-274], которая используется для оправдания диктатуры и авторитарного режима.

Конституционализм может появиться только при определенном уровне развития производительных сил, позволяющем освободить человека от поглощающего его производительного труда. К конституционализму не могут перейти страны с преимущественно сельскохозяйственным производством, не прошедшие этап экономической модернизации. Консерваторы, стремящиеся доказать, что отдельные страны неспособны перейти к конституционным отношениям, придерживаются идеалистического подхода. Они доказывают, что менталитет отдельных народов неизменен, что существует определенная «матрица», от которой невозможно отказаться [2, с. 24-29]. Исто- 
рия человечества легко отрицает эти идеи. Все народы шли от варварства к цивилизации. Общественное сознание консервативно, но оно изменяется вместе с изменением условий жизни.

Известно, что часть доконституционных стран поддерживает высокий уровень жизни своего населения и удовлетворенность архаичной монократической формой правления в результате получения этими странами природной ренты. Отказ развитых стран мира от углеводородного сырья и переход к использованию новых источников энергии снизит доходы сырьедобывающих государств [3]. Правители этих стран не смогут подкупать свое население и потеряют социальную опору своей власти. Они вынуждены будут либо сохранять свою власть, опираясь только на насилие, либо отдать ее обществу, его представителям (публичным политикам и парламенту).

3. Для решения поставленных исследовательских задач конституционная инноватика должна опираться на собственную методологию. Философской основой конституционной инноватики является диалектика с ее убеждением в том, что человечество не может остановиться на достигнутом и будет постоянно развиваться. Законы диалектики указывают на пути движения человечества от доконституционного к конституционному строю через борьбу старого с новым, через накопление количественных изменений в обществе, которые ведут это общество к качественному скачку к конституционализму.

При изучении движения стран мира от доконституционного строя к конституционному автор предлагает не отказываться от разделения государств на типы в зависимости от их классовой сущности. Кроме традиционно выделяемых марксизмом, предлагается обратить внимание на административный тип государства, обеспечивающий доминирование над обществом административного класса, из которого состоит государственный аппарат [4]. Именно этот тип государства сегодня имеет место в Китае и России. Мировое развитие сегодня выглядит, как борьба административных доконституционных систем с буржуазно-конституционными системами [5, с. 22-33]. От результатов этой борьбы зависят темпы перехода человечества к конституционному строю во всем мире.

По мнению автора, в рамках конституционной инноватики следовало бы недогматически использовать все имеющиеся концепции развития общества, начиная с идей Просвещения. Сама вера в эволюцию и социальный прогресс вселяет в людей оптимизм и поддерживает их энтузиазм в борьбе за демократию и республику. Некоторые общества все еще не прошли этапа Просвещения. Люди верят в неизменность мира и стараются остановить развитие. Все полезное следует взять из теории модернизации. Особый интерес сегодня представляет теория догоняющей (вторичной) модернизации. Конституционные страны показывают более высокий уровень развития экономики, науки, дают более высокий уровень жизни своему населению. Они неизбежно будут служить образцом для подражания во всем мире (soft power). При современных средствах распространения информации диктаторам доконституционных стран не удастся выстроить эффективно действующие «железные занавесы». Информация о жизни в конституционных странах диффузионным путем будет проникать везде и подтачивать власть автократов.

Как и любая наука, конституционная инноватика не может обойтись без формулирования своих идеальных моделей конституционализма (как идеологии), конституционного и доконституционного строя. Она вырабатывает свои понятия прогресса и модернизации, связанные с изменением общественных отношений. При использовании антропологического подхода конституционная инноватика формулирует понятие и признаки «человека конституционного», обладающего собственным достоинством, 
способностью осознавать личные и коллективные интересы, действовать организованно. Предполагается, что люди от инстинктов стадности способны перейти к отношениям коллективизма.

Конституционная инноватика применяет традиционные для современных наук методы исследования: системный, институциональный, функциональный. Следует выделить субъектов, заинтересованных в переходе к конституционным отношениям, и субъектов, втягиваемых в этот процесс. Практика показывает, что заинтересованными является группы предпринимателей (в Европе XIX в. - «третье сословие»), объединенные с гражданской интеллигенцией, которые, как уже отмечалось выше, стараются поставить под свой контроль государство как корпорацию бюрократии (административный класс). Для успешности перехода к конституционным отношениям они должны научиться привлекать на свою сторону массы населения. Естественным противником этого перехода является административный класс, который не желает терять своего господствующего положения. Союзником его выступает клиентистская буржуазия, получающая сверхдоходы от связи с чиновниками, и служилая интеллигенция, получающая плату за обеспечение идеологической поддержки авторитарной власти.

Конституционная инноватика должна изучить все факторы, обусловливающие существование доконституционного строя, и факторы, ведущие к возникновению конституционных отношений. В этом вопросе политологи должны тесно сотрудничать с социологами, экономистами, культурологами и психологами.

Конституционная инноватика должна решить для себя вопрос о допустимых сегодня средствах и методах борьбы за конституционный строй в мире. В XIX в. переход от доконституционного строя к конституционному чаще всего происходил через кровавые революции и гражданские войны. Сегодня мир стал более гуманен. Широкое распространение получили «цветные революции», носящие мирный характер («революция гвоздик» в Португалии, «бархатные революции» в странах Восточной Европы). Но успешно «цветные революции» проходят только там, где диктаторы не готовы проливать кровь своих подданных. Что делать, если диктатор переходит к массовым репрессиям?

4. Особый интерес для конституционной инноватики представляет изучение процесса перехода от доконституционного строя к конституционному. История показала, что он не является «победным шествием» от одного состояния к другому. Этот процесс носит нелинейный характер. Страны мира, сделав шаг или рывок к конституционализму, как правило, затем отступают на полшага назад. Это легко проследить на примере истории Франции XIX в. После каждой революции в стране происходила частичная реставрация старого порядка. Только революция 1870 г. вывела Францию на твердую дорогу конституционализма. Нередки случаи, когда революции, начинавшиеся под лозунгами конституционализма, завершались установлением административного строя с восточной деспотией (Россия, Китай). Автор называет эти революции административными [6, с. 221-253]. Они особенно типичны для отсталых стран, которые в XX в. назывались странами «третьего мира». Скачки назад не являются случайностью. Они закономерно связаны с мощью административного класса, формируемого в ходе революционных событий, или освободительного антиколониального движения из протоэлит, опирающихся на массу населения, не способного использовать конституционные инструменты для реализации своих интересов.

Мировая практика показывает, что сторонники перехода к конституционализму могут торопить развитие событий, пытаться внедрить конституционные нормы там, где для них нет социальной базы. Результатом этого чаще всего является появление 
имитаций перехода страны к конституционному строю. Так, в Латинской Америке первые конституции были приняты в начале XIX в. К реальному конституционализму эти страны сумели перейти только в конце XX в. Попытки перейти к конституционным практикам (свободным выборам) в странах, где население не стало разумным народом (автор отличает «народ конституционный» от масс, не способных поддерживать конституционный строй) [7, с. 13-17], могут заканчиваться возвратом этих стран к отношениям, типичным для Средневековья. Примером является проведение свободных выборов в Алжире в 1990-1991 гг. [8, с. 56-57], которое чуть было ни привело к власти мусульманских фундаменталистов. Демократическая революция в Египте (2011- 2012 гг.) и проведение свободных выборов закончились приходом к власти исламского проповедника, который попытался ввести в светской стране законы шариата.

Актуальным для конституционной инноватики остается вопрос о том, с какого уровня должно начинаться движение к конституционализму: «сверху», через захват власти сторонниками конституционализма или снизу, с формирования муниципального самоуправления. История показывает, что элитам, «зараженным» идеями конституционализма, никогда не удавалось внедрить его в общественные отношения искусственным путем. Но они могли расчистить путь для конституционного развития страны, создать условия для движения по пути конституционализма.

При изучении процессов конституционализации в отдельных странах встает вопрос о роли личности в истории. Как известно, талантливые и энергичные правители могли на долгие годы остановить процесс демократизации отдельных стран. Энергичные представители контрэлит могут организовать свержение диктаторского режима. Но вновь следует отметить, что конституционный строй может возникнуть только там, где значительные группы населения представляют собой народ, сознающий свои интересы, организованный и способный участвовать в управлении делами общества и государства. Конституционализм не может быть без демократии. Его нельзя ввести «сверху».

Особый интерес для конституционной инноватики представляет стадия имитации конституционного строя. Значительное количество стран сегодня находится именно на этой стадии своего развития. Сегодня осталось мало стран мира, руководство которых может открыто заявить, что оно вполне обходится без суверенитета народа, демократии и республики. Большая часть стран, не имея возможности и желания перейти к конституционному образу жизни, создает видимость такого перехода. Даже в Северной Корее принята конституция, которая провозглашает власть народа, демократию и республиканскую форму правления [9, с. 308-334]. Необходимо изучать субъектов, заинтересованных в имитации конституционного строя, участников имитационной деятельности, применяемые ими средства, пути, методы, приемы и технологии имитаций. Мировой опыт имитации конституционного строя описан автором в его четырехтомной монографии [10]. Для имитации конституционного строя в стране принимается ложная или формальная конституция. Аборигенные институты получают конституционные названия. Правителя называют президентом, его помощника - премьер-министром. Патерналистское государство выдается за социальное, а полицейское - за правовое. Имитация конституционного строя осуществляется через действия ритуального характера. В стране могут производиться управляемые выборы и референдумы, обеспечивающие правителю пожизненное правление. Для обозначения демократии применяется дозированное дозволение использовать те или иные политические права с разрешения чиновников и под их надзором (дозированное использование свободы слова, права собираться мирно). В стране может имитироваться 
многопартийность. Неоценимую роль в имитации конституционного строя играет служилая интеллигенция, которая создает теории ложного конституционализма (советского, исламского и т. д.), «лакирует» действительность, утверждая, что конституционный строй в стране уже возник. Исследования имитаций конституционного строя объединяются автором в особое направление научной мысли, которое называется конституционная имиджелогия.

В период перехода от доконституционного строя к конституционному многочисленными являются отклонения от норм и принципов конституционализма, выработанных политической философией. Изучение этих отклонений объединяется в рамках научной дисциплины, называемой конституционная девиантология [11]. К сожалению, отечественная наука мало обращает внимание на механизм нейтрализации (блокирования) конституционных идеалов, в том числе через законы. Многие в России не понимают, что конституционные акты могут иметь ложный или мнимый характер, т. е. в них могут закрепляться нормы, не соответствующие конституционной идеологии. В этом случае мы говорим о неконституционных конституциях (нормах конституции) [12, с. 185-196]. Неконституционными могут быть поправки к конституции [13, c. 321-341]. Нормативные акты, которые закрепляют конституционные идеалы, но не работают на практике, называются формальными (номинальными или бумажными) [12, с. 197-198]. Отклонения от конституционных идеалов могут быть не только в виде действий (захват власти группой общества, фальсификация результатов выборов). Девиантными могут быть политические институты: монократическая форма правления, авторитарный режим, неправовой характер государства. Отклоняющимся от конституционного идеала может быть общественное сознание, политическая культура (патриархальная или подданническая).

5. Особое развитие в рамках конституционной инноватики должно получить направление изучения истории движения мира (всеобщая история) и отдельных стран к конституционализму. Это направление должно осваиваться совместно политологами и историками. Необходимо обратить внимание на то, что историю борьбы за конституционализм обычно представляют как историю развития конституционной мысли, которая может иметь маргинальный характер и быть совершенно чужда обществу [14]. Юристов, как правило, интересует только правотворческая деятельность государства.

Наибольший интерес вызывает история тех стран, которые завершили переход к конституционному строю. На основе этой истории можно построить гипотезы развития стран, только вступивших на путь перехода к конституционализму. Конечно, важным является также изучение истории неудач перехода к конституционализму, например, в африканских странах. История конституционных инноваций дает материал для обобщения и выявления закономерностей движения мира от доконституционного строя к конституционному.

Безусловно, одним из важных разделов конституционной инноватики является сравнительное изучение внедрения конституционных норм в разных странах мира. Важным является не только страновое, но и темпоральное сравнение. По мнению автора, Россия сегодня вновь переживает период становления капитализма и распространения в обществе конституционных идей, который уже прошла в конце XIX в. начале XX в. Отсюда вытекает предположение о грядущей революции, которая в марксистской литературе называется буржуазно-демократической. Как известно, революции могут быть и бескровными. Они могут происходить «сверху». К сожалению, сравнительное правоведение в России ограничивается сопоставлением только текстов конституционных актов и не уделяет внимания общественным процессам перехода 
разных стран от доконституционной стадии к конституционной. Приятным исключением из этого правила является работа А. Н. Медушевского «Теория конституционных циклов» [15].

6. Отдельным направлением исследования внутри конституционной инноватики является конституционная футурология. Будущее стран, не имеющих конституционного строя, можно предвидеть, сравнивая их с конституционными странами на определенных этапах их доконституционного развития. Уже отмечалось, что Китай идет по германскому пути. Здесь капитализм строится сверху, причем под лозунгами коммунизма. Административный класс сам создает своего могильщика в лице собственников капитала. Уже сегодня им разрешено вступать в Коммунистическую партию Китая. Постепенно они превратят государственную бюрократию в свой послушный инструмент и научатся решать сложные для страны вопросы путем согласования и компромиссов через республиканские инструменты, которые постепенно перестанут быть только фикцией. Метод экстраполяции, примененный для изучения последних 300 лет человеческого развития, указывает на то, что конституционные отношения постепенно во всем мире вытесняют доконституционные.

Современная футурология дает сценарии развития будущего мира и отдельных стран. Оптимистичным для распространения конституционализма в мире является сценарий близкого «конца истории». При негативном сценарии доконституционные государства, опираясь на поддержку Китая, просуществуют еще довольно долго. До сих пор глобализация способствовала распространению конституционных отношений в мире. Но сегодня процессы глобализации возглавляются Китаем, который поддерживает диктаторские формы правления в странах, являющихся его сырьевыми придатками. Для руководства Китая иметь дело с коррумпированным диктатором проще, чем с парламентом, выражающим интересы народа.

При определении перспектив развития того или иного общества конституционная инноватика должна прибегать к использованию синергетического подхода. Как известно, использование метода экстраполяции при построении прогнозов развития отдельных стран часто дает ошибку и обеспечивает знание только на ближайшее будущее. Надо иметь в виду, что доконституционные общества, как правило, не умеют избегать кризисов. Их правители сами доводят развитие страны до накала страстей, до революционной ситуации. На каком-то этапе, часто связанном с передачей власти от одного правителя к другому, страна попадает в точку бифуркации. Неизвестно, какой путь она выберет: сделает резкий скачок назад, к своему прошлому, или начнет строить конституционные отношения. Предпосылки обычно есть и для того и для другого. Большую роль здесь может сыграть случайность, решительность лидеров консервативных или прогрессивных сил.

7. Безусловно, знание законов инновационных процессов позволяет конституционной инноватике реализовать прикладные функции. Она может прямо встать на службу политических сил, заинтересованных в движении страны и мира к конституционным отношениям. Опираясь на имеющиеся знания, политтехнологи могут помогать политикам вырабатывать программы действий, направленных на конституционные реформы, на противодействие силам, мешающим стране двигаться к конституционным идеалам. Конституционная инноватика может указать сторонникам движения к конституционным ценностям возможные пути, средства, приемы и методы достижения поставленных целей. Исследователи должны предложить политикам как минимум две программы. Одна - рассчитанная на движение в рамках устоявшейся «колеи». Другая программа должна начать действовать в случае попада- 
ния страны в точку бифуркации. Первая программа включает в себя медленные и, может быть, малозаметные преобразования общества. Вторая программа должна предвидеть решительные действия по овладению власти и нейтрализации антиконституционных сил в точке бифуркации. Здесь встает ряд вопросов о том, с чего начинать. Следует ли начинать реформы с экономических преобразований (ликвидации государственных монополий и редистрибуции, являющихся основой экономического господства административного класса) или в первую очередь произвести демократические преобразования. Очевидно, что общих рекомендаций для всех стран выработать невозможно. Следует учитывать то состояние, в котором находится страна, наличие элит, способных проводить конституционные реформы, наличие социальных групп, готовых их поддержать. Португалия и Испания быстро перешли от диктатуры к конституционному строю, поскольку это были буржуазные страны. Им пришлось изменить только политическую надстройку. Путь России к конституционализму не может быть легким и быстрым. У нас все еще нет ни буржуазной (конкурентной) экономики, ни сильного класса предпринимателей. Как отмечалось выше, построить конституционализм без социально-экономической базы невозможно.

Наибольший интерес для прикладного направления конституционной инноватики представляет теория транзита (А. Пшеворский, Ф. Шмиттер, Х. Линц). Она выделяет социальные силы, способные продвигать демократические преобразования, указывает на попутчиков и противников преобразований [16, с. 109-110]. Теория транзита разработала тактику и стратегию движения к демократии, выделила стадии этого продвижения и указала на возможные модели перехода [17].

Программа медленных реформистских действий включает в себя распространение в обществе конституционных идей через образование и воспитание его членов, через пропаганду и агитацию. Необходима выработка технологий осуществления этой деятельности. К сожалению, большая часть юристов поражена болезнью юридического романтизма. Они считают, что достаточно придумать хорошие нормы конституции, и страна тут же начнет жить по-новому. Политологи понимают, что это не так. Массы надо убедить, что новое будет лучше старого. Нужна кропотливая деятельность по внедрению институтов демократии.

Разработка программ внедрения конституционных норм и принципов в жизнь отдельных стран, естественно, должна опираться на опыт стран, уже прошедших этим путем, на методы компаративистики. Понятно, что история не может повториться, но из нее надо взять все полезное.

Интересным для прикладной конституционной инноватики является вопрос о тактике борьбы за конституционные идеалы. Допустимо ли для достижения конституционных целей применять неконституционные средства насилия, обмана, манипуляции общественным мнением. Конституционная идеология носит секулярный характер. Следует ли ее сторонникам прибегать к религиозным способам ее оправдания. На практике это систематически осуществляется. В США борьбе за свободу и республику в конце XVIII в. придавали явно сакральный характер. В условиях имитации конституционного строя правящая группа принимает конституционный акт, содержащий в себе явно неконституционные нормы, законы антиконституционного характера. Используя риторику правового государства, она требует от членов общества подчиняться этим неконституционным нормам. Понятно, что эта риторика может обмануть только наивных людей. Борьба за право [18, с. 22, 65-74], за конституционализм требует от их сторонников сделать все, чтобы устранить эти антиконституционные нормы конституции и законов. Борьба за власть часто требует от сторонников республики и демо- 
кратии идти на компромиссы с явно антиконституционными силами. Вопрос о допустимости этого носит ситуативный характер. Надо иметь в виду, что мир не делится на «хороших» сторонников конституционализма и «плохих» антиконституционалистов. Национализм не обязательно превращается в нацизм. Не все «левые движения» требуют установления диктатуры.

Исторические процессы всегда отчасти носят открытый, а отчасти скрытый характер. Естественно, в условиях авторитарных режимов подготовка общества к конституционализму вынуждена уходить в тень. Она должна осуществляться скрытно, не вызывая подозрения у правящего административного класса. Конечно, следует принимать возможные меры для раскола самого этого класса, выделения в нем так называемой либеральной группировки, готовой на сотрудничество с обществом [16, c. 681-685].

8. Отдельный раздел внутри конституционной инноватики посвящается изучению глобальных процессов развития человечества. Очевидно, что конституционные страны постараются преобразовать весь мир по своему образу и подобию. В этом заинтересована буржуазия этих стран. Она стремится создать глобальный рынок, на котором капиталы свободно перемещаются из страны в страну и имеют везде одинаковую защиту. Идеология гуманизма, присущая конституционным странам, требует одинаковой защиты прав и свобод человека и гражданина, где бы он ни находился. Мир прошел тот период, когда войны приносили огромные доходы. Сегодня большая часть буржуазии не хочет войны. Конституционные страны больше не воюют между собой. Угроза миру исходит от стран, где по-прежнему господствуют административные элиты и правители с отклонениями в психике способны начать войну с соседями для реализации своих честолюбивых планов. Исходя из этого, конституционная инноватика должна предложить политикам пути трансформации отсталых стран. Она должна дать оценку эффективности применяемых сегодня технологий воздействия на доконституционные страны. В частности, не решен вопрос о допустимости применения насилия против диктаторов отдельных стран, которое неизбежно выливается в применение военной силы.

Мировая практика борьбы с антиконституционными режимами широко применяет метод санкций. Эти санкции могут быть направлены не только против конкретных представителей правящих режимов, но и против страны в целом. Наука должна оценить эффективность этих мер для внедрения конституционных норм в отсталые страны. Очевидно, что рост бедности в стране, против которой применяют санкции, может вызвать возмущение населения против своей правящей группы, но вряд ли приведет к переходу страны к конституционным отношениям. Бедные не являются социальной базой конституционализма $[19$, с. 5].

Все указанные выше подходы к конституционной инноватике могут быть применены к исследованию внедрения отдельных элементов конституционализма: республики, демократии, прав человека, правового государства, федерализма и местного самоуправления. Естественно, изучение борьбы за права человека и гражданина разбивается на исследование борьбы за политические права, за права женщин, детей, меньшинств и т. д.

Итак, в рамках политологической науки России появилось новое направление научных исследований - «конституционная инноватика». У него большое будущее, и оно ждет своих исследователей. 


\section{Ссылки / References}

1. Денисов С. А. Административное общество. Екатеринбург: Гуманитарный университет, $2011.608 \mathrm{c}$.

2. Кирдина С. Г. Институциональные матрицы и развитие России. М.: Теис, 2000. 21 с.

3. JPMorgan: борьба с изменением климата больно ударит по России и другим странам // ProFinance. 18.09.2020. URL: https://profinanceru.turbopages.org/profinance.ru/s/news/2020/09/18/bzg1-jpmorgan-borba-s-izmeneniemklimata-bolno-udarit-po-rossii-i-drugim-stranam-em.html (дата обращения: 12.11.2020).

4. Денисов С. А. Общая теория административного государства. Екатеринбург: Гуманитарный университет, 2010. 684 с.

5. Денисов С. А. Конец истории откладывается на неопределенный срок // Политическая концептология: журнал метадисциплинарных исследований. 2013. № 1. С. 22-33.

6. Денисов С. А. Великая административная революция 1917-1920 гг. в России // Проблемы истории общества, государства и права. Сборник научных трудов. Вып. 10. Екатеринбург: Уральский государственный юридический университет, 2020. С. 221-253.

7. Денисов С. А. Реальное государственное право современной России: монография. В 3 т. Т. 2. Екатеринбург: Гуманитарный университет, 2016. 411 с.

8. Современная Африка: метаморфозы политической власти. М.: Восточная литература, 2009. 494 c.

9. Конституции социалистических государств. Сборник в 2 т. Т. 1. М.: Юридическая литература, 1987. 336 с.

10. Денисов С. А. Имитация конституционного строя: в 4 кн. Екатеринбург: Гуманитарный университет, 2018-2019.

11. Денисов С. А. Конституционная девиантология (общая теория): В 3 кн. Книга 1. Наука конституционной девиантологии. Конституционные девиации. Екатеринбург: Гуманитарный университет, 2020.594 с.

12. Денисов С. А. Реальное государственное право современной России: монография. В 3 т. Т. 1. Екатеринбург: Гуманитарный университет, 2015. 348 с.

13. Barak A. Unconstitutional Constitutional Amendments // Israel Law Review. 2011. Vol. 44. № 3. P. 321-341.

14. Из истории конституционализма в России: проекты и конституции XVIII-XX веков: к 20летию Конституции Российской Федерации. СПб.: Президентская библиотека, 2014. 106 с.

15. Медушевский А. Н. Теория конституционных циклов. М.: Издательский дом ГУ ВШЭ, 2005. 576 c.

16. Пшеворский А. Переходы к демократии. Глава VII. Власть верховная и управительная // Политология: хрестоматия. М.: Гардарики, 1999. С. 681-685.

17. Карл Т. Л., Шмиттер Ф. К. Демократизация: концепты, постулаты, гипотезы (Размышления по поводу применимости транзитологической парадигмы при изучении посткоммунистических трансформаций) // Гражданское общество в России. URL: http://www.civisbook.ru/files/File/Karl_2004_4.pdf (дата обращения: 17.02.2020).

18. Ильин И. А. О сущности правосознания. М.: Рарогъ, 1993. 235 с.

19. Липсет С. М., Сен К-Р., Торрес Д. Ч. Сравнительный анализ социальных условий, необходимых для становления демократии // Международный журнал социальных наук. Сравнительная политология. 1993. № 3.10. С. 5-17. 